\title{
On Problems \& Countermeasures of Archive Management of Veterans in New Era
}

\author{
Saisai $\mathrm{Li}^{*}$ \\ School of Public Administration \\ Shandong Technology and Business University \\ Yantai, China
}

\author{
Zhenqi Liu \\ School of Public Administration \\ Shandong Technology and Business University \\ Yantai, China
}

\begin{abstract}
The problems and countermeasures of the management of veterans' archives are based on a summary of the current status of the management of veterans' archives in the new era. The main problems are analyzed and corresponding countermeasures are proposed. Veterans' archives management is a confidential, professional, complex, and trivial task. It is of great importance and special significance to manage the archives of the veterans well in the work of setting the veterans. The series of measure proposed in this article will better advance our work and protect the rights and interests of veterans.
\end{abstract}

Keywords-veterans; archive management; problems; countermeasures

\section{INTRODUCTION}

Mr Lin, enlisted in 1978, retired as a disabled soldier in 2010. In the same year, the superior issued an order for resettlement. When his army handed over the archives to the Civil Affairs Bureau of Lin's resettlement place, it was delayed and rejected by the local competent department in charge of resettlement for various reasons. After many investigations and consultations, no results were obtained. Until 2020, Lin's archives have been kept in the army, and was not received by the resettlement site. As a disabled and retired soldier, Mr Lin has not been resettled successfully for ten years. One of the important links is the transfer of archives, that is, there are certain problems in archive management.

\section{Status OF Veterans ARChiVES MANAGEMENT IN CHINA}

Veterans' archives are a true record of military personnel's work and personal performance during the army, mainly including enlistment materials, party(regiment) materials, military ranks, position promotion(adjustment) materials, reward and punishment materials, training, assessment materials, life benefits materials, non-commissioned officer materials, retired materials, and other materials required to be put on archive as required. Veterans archives discussed in this article refer to archives of general veterans. Veterans' archives are important evidence for military personnel to be resettled and enjoy preferential military and land policies after they are discharged. They are also an important reference for safeguarding the legitimate rights and interests of veterans, investigating and appointing them.

Fund Project: Graduate Science and Technology Innovation Fund Project of Shandong Technology and Business University "The Insurance System of American Veterans and Its Enlightenment”, No.2019YC016.

\section{A. Overview of the Formation and Transfer of Archives}

During the service of the soldiers, the archives are kept by the army and entered into the soldiers' archives management system. When the soldiers retire, they transfer archives to different agencies for management according to their individual circumstances. The general process of forming a file of veterans is as follows: When a soldier joins the army, the People's Armed Forces Department where the household registration is located collects its basic information and creates a file for him or her. After enlistment, the archives are uniformly received by the military affairs department, and all records formed by soldiers during service are strictly managed [1]. After retired, according to the individual's different resettlement methods, the archives will be transferred to different administrative departments in a centralized manner or by mail. The resettlement methods for soldiers after retirement are mainly the combination of retirement, active employment, job placement, retirement, support, and continuing to complete their studies. In order to regulate the placement of veterans and protect the legitimate rights and interests of veterans, Article 14 of Chapter II of the "Regulations for the Settlement of Veterans" states that "Veterans shall, in accordance with the relevant provisions of the state archives management, transfer their archives to the resettlement department of veterans of the people's government at or above the county level in the resettlement place in a timely manner when they are retired". After the soldier retires, in accordance with the relevant provisions of the national archives management. When the soldiers retire, their archives should be transferred to the resettlement department of the veterans in the resettlement place in time.

\section{B. Archives Management Department}

Ministry of Veterans Affairs of the People's Republic of China is responsible for the affairs of veterans, and the archives of veterans have begun to be managed centrally. With the establishment of Ministry of Veterans Affairs of the People's Republic of China, corresponding veterans management agencies have also been established in various places to manage veterans affairs. In the process of receiving the veterans' archives, the archives of veterans were transferred from the original civil affairs department and the human resources department to the local veteran's department for management and preservation. 


\section{Relevant Policies and Regulations}

The policies and regulations related to the management of archives of veterans mainly include the "Army Archives Regulations", "Procedures for the Handover and Review of Veterans' Archives (Trial)" (hereinafter referred to as the "Procedures"), "Regulations on the Placement of Veterans", and "Procedures for Handover and Resettlement of Disabled Veterans (Trial)". The "Regulations on the Placement of Veterans" is formulated in accordance with the "Military Service Law of the People's Republic of China". The "Procedures" are a procedural norm for the transfer and review of archives of veterans. Adopted strict procedures, standards, and requirements to organize the review of the transfer of veterans' archives to ensure the smooth transfer of veterans.

\section{Form of Archival Information}

At present, the archives in our country are mainly based on traditional management methods, and most of them are in the form of paper materials in the process of archives establishment, transfer and use.

\section{PROBlEMS IN THE MANAGEMENT OF VETERANS' ARCHIVES}

At present, the number of veterans is gradually increasing, and the management of veterans' archives is a confidential, professional, complex, and trivial task, which makes the resettlement work increasingly difficult. After the establishment of the Ministry of Veterans Affairs of the People's Republic of China, the interests of the veterans' group were effectively protected to a certain extent. However, there are still some veterans who do not receive the treatment they deserve, which affects their normal lives. The main problems are as follows.

\section{A. Archives are Incomplete and Poorly Kept}

Our country sets archives should be kept in an archive room, which must be managed by special personnel and kept properly Since the establishment of the Veterans Administration, the archives of veterans have been transferred from the original civil affairs department and the social affairs department. On the one hand, the information and materials are lacking in integrity, and some veterans have fewer archives and materials. On the other hand, due to the different main body of the archives being kept by soldiers at different stages, in the process of transferring the archives, it is easy to miss or lose data due to poor operation. All of these have extremely adverse effects on the development of related work in the later period.

\section{B. Lack of Awareness of the Importance of Archives}

In recent years, the work of veterans in our country has been continuously reformed and developed, and the corresponding policies have also changed. The service life of veterans and honors and medals during the service period are related to many preferential policies such as retired placement. This information is stored in individuals archive. Previously, relevant departments had insufficient understanding of the storage and importance of archives, which led to a lack of emphasis on archives management.

\section{Veterans' Archives Management Lacks Professional High- Quality Talents}

In 2018, the Ministry of Veterans Affairs of the People's Republic of China was established, and most of the members of the organization were transferred from other positions. Although there are military personnel involved and a more detailed understanding of the veterans' work, many people only know the outline of veterans' archives management. They need to learn from the basics. There is a shortage of archival technicians. This is also particularly important from a local perspective. Provinces, cities, and counties, from top to bottom, the lower the level of villages and towns, the more serious the lack of professional management personnel is. This has further led to problems in archives' management and archives' transfer errors.

\section{Imperfect Management System}

As a newly formed department, the Ministry of Veterans Affairs of the People's Republic of China is very diverse. All aspects of work are being sorted out. The system of archives management is not complete. Procedures for receiving, transferring, and using archives are lack of standardization and there is no uniform management standard. For example, article 14 of the "Regulations on the Placement of Veterans" "The troops where veterans belong shall, in accordance with the relevant provisions of the State Archives Management, transfer their archives to the resettlement department for veterans of the people's government at or above the county level in the resettlement place in a timely manner". Among them, it only mentioned "timely", without specifying a specific time limit.

\section{E. Poor Management}

The archives of veterans have huge information, and there are many paper materials. The current management methods can no longer meet the new characteristics and requirements of development. Data storage is cluttered, it takes time to find and search information, delays in handover work, and repeated work procedures are common problems. A lot of manpower, material and financial resources have been wasted, and the management of veterans' archives is very difficult.

\section{SUGGESTIONS FOR IMPROVING THE MANAGEMENT OF VETERANS' ARCHIVES}

How to standardize the management of archives so that veterans can enjoy their due benefits and protection quickly and in a timely manner, safeguard the legitimate rights and interests of veterans, and then better promote army building and serve the national defense cause has become an urgent social issue.

\section{A. Complete Veterans' Archives}

Archives should be placed in a dedicated archives management room. Archives managers should classify, inspect, and organize the archives, and then find out the missing parts of the archives. They should contact the individuals and relevant agencies and departments in time to complete the data. Ensure the integrity of archives. During the transfer, management, and use of archives, detailed registration records 
are required to ensure detailed information. At the same time, Veterans' archives must be kept in strict accordance with Chinese relevant confidentiality laws to ensure the security of veterans archive information. Maintain the security of archival materials [2].

\section{B. Improve the Ideological Understanding of the Importance of Archives' Management}

On the one hand, the state can set up an official website on the management of veterans' archives to increase the attention of the whole society. China wants to set up an official website on veterans archives management, which can imitate the establishment of a military archive section by the United States Department of Veterans Affairs(VA). Not only can the relevant departments pay more attention to the management of veterans' archives, but also can make the veterans management system simple and convenient for centralized processing of affairs. On the other hand, the department in charge of resettlement of veterans should closely follow the central ideological policy and change their ideology. And they must effectively recognize the important role of veterans' archives in formulating and implementing policies and regulations, carrying out preferential treatment for the support of the army, implementing resettlement, and improving service management. Archivists should always keep in mind their responsibilities, be in their place, be safe, and be honest. In addition, all departments should actively carry out publicity work. Publicize the latest policies on the preferential treatment and placement of veterans, and publicize the procedures and materials required for the placement of veterans [3]. Fundamentally and practically raise the whole social attention to the management and placement of retired military personnel and respect for retired military personnel, and also provide more "heartwarming" services for retired military personnel [4].

\section{Cultivate Professional Talents and Strengthen the Training of on-the-job Personnel}

On the one hand, it is necessary to train professional talented students as reserve resources troops and continuously expand the veterans archives management team to cope with the increasing number of veterans. In this regard, China has started to take measures to jointly train graduate students in the direction of "management and security of veterans" with designated universities, and has achieved initial results. The smooth development of this pilot work will bring constructive reference opinions to other colleges and universities, allow more colleges and universities to be exposed to this profession, participate in the work of retired military personnel, and cultivate reserve talents for the country. On the other hand, organize management training on a regular basis. Increase the rigorous assessment mechanism and publicly evaluate the results. The assessment system is to improve the work efficiency of employees, and the results of the assessment provide the basis for the rise and fall of employees. Through the training and assessment mechanism, the professionalism of management personnel is enhanced, and strong professional technology is created. Improve management capabilities and promote standardized work.

\section{Improve the Institutional Mechanism and Laws and Policies}

Department of veteran affairs should formulate a set of rules and regulations suitable for the management of veterans' archives in accordance with Chinese laws and regulations related to archives management. Unify standards and standardize management, and implement responsibility to individuals. Make the work rule-based and promote the systematization and transparency of the receipt, transfer and borrowing of veterans' archives, and improve the standardization of archive management [5]. Article 16 of "Regulations on the Placement of Veterans" stipulates that "veterans should be responsible for handling issues related to service; when problems related to resettlement occur, the people's government of the resettlement place should be responsible for handling them". When the veterans' archives are rejected during the transfer process, causing resettlement problems, it may not be possible to achieve the purpose of resettlement by only the people's government of the resettlement place. At this time, it is necessary to strengthen the communication between the original army and the resettlement place to solve the problem together. In order to avoid this situation, the state should also amend some laws and policies in due time according to the actual situation. For example, during the transfer of archives, should there be a clear time limit for the transfer of archives by the army of veterans to the place of resettlement. As in the case mentioned at the beginning of the article, what should be done if there is no resettlement at the resettlement site due to the delay in accepting the archives, whether to set up a third-party monitoring agency to supervise and promote the resettlement of veterans. These are all questions worth thinking about. The improvement of regulations and policies can better promote the smooth progress of archives management and better protect the deserved benefits of veterans.

\section{E. Establish an Electronic Archiving Information System}

In the context of big data, the total amount of information is large, showing the characteristics of diversity, speed, and high value, and the data acquisition and transmission methods are more flexible. Traditional paper archives management methods can no longer meet the needs of development, and urgently require modern management methods. The electronic information archiving system aims to provide intelligent information services. The introduction and application of big data and cloud computing analysis technology in management work will effectively improve the veterans archives management capabilities. The collection, reading, search, and transfer of information will greatly improve the accuracy and efficiency level, and it will be more convenient and rapid to share information among different agencies and departments. The newly revised "Army Archives Regulations" in 2019 added an electronic archiving system [6], which stipulated issues related to the management of electronic archives, clarifying that electronic archives have the same legal effect as paper archives. Among them, the electronic archive system of some counties in Guizhou Province, and the "electronic archive database" of Fuxin City, Liaoning Province [7], are all examples of successful electronic archiving management. It is worth noting that the archives' function should be provided in 
every link of the veterans archives management, and a convenient and intelligent electronic archives information system should be truly established. It is worth noting that the establishment of an electronic information archive system requires financial support from the state. Information and equipment updates require a lot of material and financial investment.

\section{CONCLUSION}

The problems mentioned above still exist in the archives management of veterans. The management of veterans archives is related to the vital interests of veterans, and it is related to the stability of the society and the long-term stability of the country. Collect the enlistment information of each soldier carefully, establish accurate and accurate archives; strengthen communication between the military and the field, and regulate the transfer of archives; carefully organize the reception of resettlement sites, and provide related services. All links are interlinked and require the attention and effective cooperation of relevant departments. Raise the professional level of veterans archives management, earnestly implement the veterans' resettlement work, and protect the legitimate rights and interests of each veteran.

\section{REFERENCES}

[1] Dan Shao, Siyi Lu, Yunting Lu, Yexin Rong, "Investigation and research on the status of veterans' archive management," 11 Inside and Out of Lantai, 2019, pp. 79-81,(In Chinese).

[2] Jiang $\mathrm{Wu}$, "Innovation of archives management mode of veteran under the information background," S2 Lantai World, 2018, pp. 171, (In Chinese).

[3] Xiaohui Xu, "Analysis of problems and countermeasures of veterans archives management," 8 Human Resource Development, 2017, pp. 22 23, (In Chinese).

[4] Liqi Shi, "Measures to do a good job in veterans file management," 6 Office Business, 2019, pp. 146, (In Chinese).

[5] Qingling Jia, 'Informatization construction of veterans' needs urgent solution," 4 Shandong Archives, 2019, pp. 65-66, (In Chinese).

[6] Ministry of Veterans Affairs of the People's Republic of China, "Managing Documents for the Party, Guarding the History of the Army, Serving the War-Comrades in charge of the Army Archives Department answer questions from reporters on the release of the newly revised" Army Archives Regulations", (In Chinese). http://www.mva.gov.cn/sy/xx/gfxx/201912/t20191218_34316.html

[7] Lei Zhao, Jianyong Xiao, "Veterans rest assured, every file is clear," China National Defense Newspaper, 17-12-2019, (In Chinese). 